\title{
The Challenges That Indonesian Students Faced in Academic Writing: A Cross-Disciplinary Study of Academic Literacies
}

\author{
Muflihun $^{1 *}$, Citra Prasiska Puspita Tohamba ${ }^{1}$ \\ ${ }^{1}$ Muhammadiyah University of Kendari, Indonesia \\ *Corresponding author.Email: muflihunrubsan@gmail.com
}

\begin{abstract}
This study primarily aimed at investigating academic writing challenges that Indonesian postgraduate students faced at The Queen's University of Belfast enrolling at academic year 2017/2018 across disciplines. Further, designed under descriptive qualitative study, twice narrative interviews conducted to gather data of this study. The finding of this study confirmed that the participants initially had common challenges in academic writing, such as developing critical thinking, avoiding plagiarism, sentence structure and few practices or training on academic writing. Critical thinking encompassed their ability to analyse, to evaluate, to infer and to interpret an idea which then reworded into their own. Those shortcomings affected their understanding on how a plagiarism could be avoided or even minimized. Additionally, less understanding on English grammar and lack of academic writing practices were among other challenges found. In terms of academic literacies, it was found that the participants had quite few interactions with academic English which influenced their ability to compose academic writing. It could be concluded that there should be more academic writing enhancement programs across universities in Indonesia to tackle those common problems while studying abroad.
\end{abstract}

\section{Keywords: Academic Writing Challenges, Indonesian International Students, Academic Literacies}

\section{INTRODUCTION}

It is commonly accepted that academic writing skills are among essential competences to succeed in university study. Hence, there have been a plethora of studies carried out to examine the importance of academic writing skills in higher education, while some findings showed why it is that some students perform badly in academic writing. This study, indeed, sought to investigate academic writing challenges of Indonesian postgraduate students studying across disciplines at The Queen's University of Belfast, Northern Ireland, UK, academic year 2017/2018.

\subsection{Background to the Study}

Building upon the centrality of academic writing, Shaheen [1] admitted that international students in the UK universities considered having lack of critical thinking in academic writing, a concern of teaching professionals and researchers. Additionally, Lin and Yi [2], Zhang and Burton [3], Campbell and Li [4] and
Burns [5] questioned how international students adjusted themselves to a new academic environment - educational system and policies, - of higher education which contextually different to their undergraduate studies. These studies concluded that international students, to some extent, had much more difficulties in coping with academic writing conventions in higher education. This underlying concern has prompted the researchers to carry out this study.

\subsection{Review of Previous Studies}

The challenges in academic writings are further exacerbated and made more complex when students are writing in a language which is not their first language. Mullins, et al. [6] revealed that international students, particularly from ESL background, had three or four times more difficulties in academic writing compared to native writers. Surprisingly, Asian ESL students, as Pecorari [7] and Mullins, et al. [6] confirmed, were different in the aspect of writing coherence as compared to western writers and starting their writing by "copying 
or imitating" which prone to committing plagiarism. Currently, Shaheen [1] stated that international students from non-western countries were struggling in meeting the demand of critical thinking in academic writing. Therefore, this study looked at academic writing challenges of Indonesian students.

\subsection{Research Question and Objective}

This study aimed at examining common academic writing challenges of Indonesian postgraduate students across disciplines at The Queen's University of Belfast academic in academic year 2017/2018.In accordance with the objective, the formulated research question is: What are the challenges that Indonesian students face when undertaking academic writing in university?

\section{LITERATURE REVIEW}

\subsection{Academic Writing in Second Language}

Practically, writing in second language has so much differences to writing in first language, Majchrzak [8]. Hyland [9]indicated five core skills need to be mastered in order to writing in second language: Content knowledge, refers to the ideas or topics that will be written; System knowledge, relates to an understanding of language structure, i.e. syntax and lexical, and appropriateness of conventions and formality; Process knowledge, relates to a set of prior writing activities, preparation, and how a writing will be completed; Genre knowledge, is the values and communicative purposes of genre in certain circumstances; and Context knowledge, is an ability to understand readers' expectation, cultural and text preferences. Additionally, Silva [10] stated that "L2 writing is strategically, rhetorically and linguistically different in important ways from L1 writing". The potential differences arguably ranged from individual differences, language and strategy learning preferences, and cultural background, Hyland [9]. Henceforth, academic writing challenges of second or foreign language writers would be critically depended on those skills and variations.

\subsection{Approaches to Academic Writing}

Lavelle and Guarino [11] coined the terms: beliefs $\rightarrow$ strategies $\rightarrow$ outcome, where a final draft of an academic writing would be much more weighed upon those processes. Similarly, Lavelle and Bushrow [12] pointed out that there has been an interrelationship of what a writer believes, and a pattern of writing strategies employed. Further, Oxford [13] summarized three main approaches in academic writing, namely: process approach, genre approach and functional approach.

In line with these approaches, Scardamalia and Bereiter [14] argued that a writer through this approach process approach - applied a set of interrelated processes; planning, drafting, revising its material, applying problem solving and goal-oriented strategies. Furthermore, EngestrÖm [15] and Prior [16] both agreed that sociocultural perspective values writing as fundamentally social activities which are frequently mediated by and developed in social context. Finally, Hyland [9] acknowledged that a certain language form has its own communicative functions. In other words, this approach required a writer to understand typical genre of writing which served a certain function.

\subsection{Academic Literacies Model}

Lea and Street [17] developed the academic literacies approach which has become of immense importance in how writing is understood in higher education (HE). Writing practices, indeed, was a "social practice", moving beyond what was written on its paper, Lillis and Scott [18]. Therefore, in order to gain better understanding on how a piece of writing produced, one needed to consider what the people did around texts, Kaufhold [19].

Practically, Lea and Street [17] have coined three major perspectives on how a piece of writing should be analysed, namely; Study skills, a skill concerned on its "surface features of language forms", i.e., sentence structure would not be a problem to a writer, Academic socialization, acculturation into disciplinary and subjectbased discourse and genre, Lea and Street [17]. Accordingly, this enabled the students or learners to recognize that various subject areas applied different genres and discourses in certain ways to construct knowledge, Bazerman [20], Berkonkotter and Huckin [21]. In other words, the students somehow have comprehended the natural ways of thinking, talking and even writing according to academic disciplinary and discourses into their daily socialization unproblematically, and Academic literacies, this model somehow was quite similar to academic socialisations in many ways, for example both models focused on interrelationship between epistemological aspects of writing practices and literacies within subject areas and disciplines, Bazerman [20], Berkonkotter and Huckin [21]. Academic literacies approaches see writing practices far beyond textual aspects of writing, such as plagiarism, feedback as well as context of individual writings. This study would also examine how students gained their past-experiences in academic writing through these three major perspectives.

\section{RESEARCH METHODOLOGY}

\subsection{Design of the Study}

This study adopted qualitative approach to investigate the developed research question and objectives. Qualitative research was applied to give detailed 
description and deeper analysis of the core substance and quality of human experience, Marvasti, [22]. Moreover, Ary, et al., [23] claimed that qualitative study examined problems under its real context, real-world settings and based on participants' perspectives to unfold reasons of events or phenomena.

\subsection{Participants and Instrument of the Study}

As the way of obtaining participants, the study adopts a purposive sampling method. Ary et al., [23] argued that qualitative researchers are purposefully selecting their participants and research settings. Therefore, purposive sampling is perceived to be enough in providing deep insight and understanding of what is being studied. Four students finally participated in this study, spreading across faculties: School of Law, School of Midwifery, School of Biological Sciences and School of Social Sciences, Education and Social Works. This enabled the researcher to gain richer data of academic writing challenges which might be varied across disciplines.

This study used in-depth narrative interviews or biographical interviews. Kim [24] argued that it is essential to create a stance in which the interviewer himself will be an active listener and our respondents or interviewees will be a narrator of their stories in their own ways. The interviews were conducted twice, where the first interview related to their experiences in academic writing during their undergraduate study, while the second related to their experiences writing at postgraduate study as international students. These two stages of interviews were recorded for the purpose of analysis. Prior to this, the participants signed a consent form as a requirement of research ethics.

\subsection{Data Analysis and Triangulation}

The raw data of these interviews was transcribed manually as an initial attempt of data analysis. Ary, et al., [23] admitted that qualitative data analysis takes much time and difficult because the massive amounts of interview scripts, audio recordings, video data, field notes and other documents which must be interpreted and examined. Therefore, Miles and Huberman [25] developed three main steps of qualitative data analysis: data reduction, data display and verification or drawing conclusion.

Further, triangulation and member checking, are among other ways to ensure validity and reliability in qualitative study. According to Bogdan and Biklen [26] reliability in qualitative studies could be said as a match between what has been identified as data by researcher and what truly happened in the real settings of the study, for instance, to what extent the comprehensiveness and accuracy of the findings. Thus, the finding of this study would be much more accurate and interrelated.

\subsection{Ethical Consideration}

Prior to conducting this study, the researchers applied ethical approval from the body of Ethic Committee of Queen's University Belfast since ethical issues are also the other essential concerns in a social research. Cohen, et al. [27] maintained that social researchers should consider about the effect of their research towards participants such as preserving their dignity. Additionally, Israel and Hay [28] also addressed that researchers are in charge to protect their participants, through building a trust, promoting research integrity, and coping with emerging challenges in their studies. the other concerns are related to anonymity and confidentiality of the participants. According to Cohen, et al. [27] the notion of anonymity refers to ways to prevent securely any information and data given by respondents as well as related to their identities. Similarly, Creswell [29] also stated that "in qualitative research, inquires uses aliases or pseudonym for individuals and places to protect identities" Therefore, in this study, the researchers used pseudonym or initials to conceal participants' identities.

\section{FINDING AND DISCUSSION}

\subsection{Finding}

\subsubsection{The Roles of Academic Writing Training}

Apart from the challenges in academic writing faced by Indonesian students, this study surprisingly revealed that all participants had quite little academic writing training while studying at undergraduate level. However, two of the participants (*P2 and P4) used to take a short course on IELTS (academic), ranged from two to six months length. Even though they mentioned that the training was not enough to improve their writing skills, they claimed that what they learned from the programs was applicable to their current writing practices, as given below:

"Oh definitely! Because all elements of IELTS included like writing, listening, and everything [especially in writing I mean] for example in writing, well, I think IELTS you should apply like the general theory of writing for example started from the introduction, body and the conclusion, but it is in the small part. And then, I think it is correlated with the writing essay here, I think it is very [very] applicable for me (P2, 21:00 - 54)"

"Basically, yes because in writing IELTS we learn about how to develop idea in bodies and how we make introductions and conclusion as well. So, generally it's [really] applicable for my current situations or writing structure in Queen's yeah (P4, 12:00 - 33)" 
Technically, The Queen's University Belfast has arranged several programs related to academic writing skills in which carried out and provided for students freely. The participants were indeed aware of the importance of the program to enhance their academic writing competences, also they commented that the university has provided enough academic writing training courses for international students. However, they stated that they had little time to fully attend the whole program till the end. As taken from the interview, they mentioned that:

"Yes of course, I have joined several times training of Ann Hagan in postgraduate school and it is very helpful... (P3, 19:54 - 20:05)”.

"To be honest, the university has provided us with many workshops in terms of writing like how to do critical thinking, proofreading... but to be honest, I did not attend the whole series of the programs... (P2, 23:49 $-24: 41)^{\prime \prime}$.

"Yeah, I took one of courses of Ann Hagan and that is [really] great, that is about critical thinking... (P4, 14:00-07)"

"Frankly speaking, I have never been involved in any academic writing tutorial or training here at Queen's $(P 1,15: 50-58)$,

\subsubsection{Academic Writing Challenges}

Writing in English as a foreign language was challenging for the participants. This was shown on the result of their interviews, as quoted below:

"[writing in English] ... it is challenging and of course demanding because it is not my native language $(* P 1,00: 44-59)$ "

“...because it is not my first or second language...we recognize English as a foreign language, so, that's why I felt so difficult... (P2, 01:21-37)"

"Definitely! It was difficult for me since I do not, I mean I still think about the grammar, the structure how to produce good sentences in English... (P3, 00:47 01:00)"

The next concerns of the participants were related to critical thinking and issues of plagiarism. When asked to define critical thinking in academic writing, all the participants explained critical thinking differently, as stated below:

"...critical thinking is yeah, I mean like when I like [make] some pro or contra, for example... I can look for some previous researchers that they pro about this thing and some previous researchers that they [like] do not or disagree... (P3, 05:59-06:26)"
"I may understand critical thinking as the compare and contrast and then I try to analyse to get the conclusion (P2, 08:26-37)'”.

"...critical thinking is when we employ new approaches or different approaches toward the currently existing theories or concepts and we further develop those existing theories or concepts to find something new... (P1, 04:16-04:42)"

"We asked the reason behind one problem not only describe why this happens, I think that is critical thinking $(P 4,04: 45-04: 52)$ '”

Even though all participants acknowledged of how important of developing critical thinking in academic writing was to avoid or even to minimize issues of plagiarism, they admitted that this was another big challenge in academic writing.

The last problem revealed by the participants was related to grammar or sentence structures. They implied that English grammar held important roles in academic writing practices. This was mainly because writing in this context requires our ability to use appropriate words or technical vocabularies in order to keep writing be coherence and cohesive, as could be seen in the extract below:

"But the grammatical problem is still there, because from the beginning I did not put too much attention on grammar, and now as I am doing academic writing $I$ found out that the most difficult, I mean the grammatical part $(P 1,07: 03-23)$

"I think it has a really big impact for the result of our writing, because one of my supervisors said it may enhance 5 up to 10 percent of our score... (P3, 10:44 11:03)"

On the other hand, when they were asked about the most challenging one of a simple essay structure introduction, body and conclusion- they agreed that developing its introduction and body paragraph wereof the most challenging, as extracted below:

"I think the body, because once I pick the topic or theme for the essay I think I already know what kind of introduction I would like to write and what kind of conclusion that I will draw in the end (P1,09:07 - 23)"

"I think body is more difficult because the points of most essays... in the body itself (P2, 08:46 - 09:01)"

"Yeah, I think introduction something... but sometimes when I have already got the introduction, I could write the body and even the conclusion... (P3, 10:19-37)"

"When I started writing, I think the most difficult one is introduction because just like the main point but right now I think it is a body... (P4, 09:51 - 59”) 


\subsubsection{Academic Literacies Model}

It was clearly stated in the findings that the participants admitted their interaction to academic writing - academic socialization- was very little. Therefore, due to their lack of academic writing socialization, the participants faced more challenges in academic writing conventions during their postgraduate study at The Queen's University of Belfast. Another important consideration was that the participants studied English in general context, not specifically in academic English or academic writing, within various academic disciplines such as, international law, nursing and midwifery, and Islamic communication and Dakwah. These factors surely affected their comprehension, principles, beliefs, and thoughts of English academic writing.

\subsection{Finding}

In the first point, academic writing training or any means of academic socialisation seemed to prove improvement in writing proficiencies of the participants. This was relatively in line with some findings of other studies mentioned that "the training of academic writings kills is essential for scientists at the start of their career, Wischgoll, [30]”. Similarly, Kellogg and Whiteford [31] contend that training interventions which designed for senior high school students might also be applicable for university students. On the other hand, the academic writing mentioned by the participants above was in form of IELTS preparation class. The training was more on general English and how to do or complete an IELTS test, which not specifically addressed on academic writing.

Further, for many international students coming from non-native English counties, writing in English could be quite problematic. Some studies on foreign or second language writing confirmed that this problem might be caused by the influences of students' first language and the context of learning. Simply, according to Rinnert and Kobayashi [32] "the writing of EFL students is affected not only by their first language (L1), but also by the educational context where they learn to write".

Currently, Fadda [33] stated that the ability to produce academic writing in English, for some ESL learners, might be influenced by some factors such as writing style, motivation, and students' native language background as well as experiences. These factors were essential in supporting academic writing development for the learners. The finding of this study reported similar cases. The participants were facing these problems because they said that English is not their first language or English is recognized as foreign language in Indonesian context.

Developing critical thinking and raising awareness to avoid plagiarism were among other challenges faced by international students. As confirmed by the findings above, the participants were somehow struggling to develop critical thinking. However, this was not a new case, a primary study on critical thinking has been conducted by Shaheen [1] who investigated how international students in UK universities develop their critical thinking. A salient point on her study revealed that educational background was not quite helpful in supporting international students to develop thinking analytically as well as creatively.

While talking about plagiarism, Adhikari [34] conducted a study to help international students avoiding plagiarism. The study concluded that the teachers should give much time for consultation and completing exercises for international students and how to cite correctly. Citing might be problematic, when the students were not given guidelines or reference materials to cite correctly and effectively.

Fortunately, the participants in this study were practically able to avoid plagiarism and to develop their critical thinking, even though this somehow was not easy in the first attempt. To develop critical thinking, some of them suggested to have more readings, to keep asking oneself, and to make some comparisons among theories and ideas to get conclusion. Besides, in respect to keep off plagiarism, the participants commonly paraphrased and quoted properly their writing.

Finally, it was also mentioned that the participants were aware of how English grammar or sentence structure could be challenging. In some studies, it was found that grammatical features were still being the part of determining criteria of academic text quality, hence this also remained problematic for academic writers from non-native English speaker, Imani \& Habil [35].

Regarding to the findings of this study, the participants were to some extent also facing challenge in English grammar. This could be seen from the interview result with one of the respondents who mentioned that grammatical problems were still apparent in his writing. But overall, the participants could manage those problems by asking for helps from lecturers, or their friends and referring to grammar books.

\section{CONCLUSION}

Based on the findings above, it could be concluded that the participants had only little experiences on academic writing practices while they were in their undergraduate studies. This surely influenced their academic writing skills in their current writing conventions. Therefore, the participants had similar challenges on academic writing, such as writing in foreign language, developing critical thinking, understanding plagiarism, and problem with sentence structures or grammaticality. 


\section{ACKNOWLEDGMENTS}

This research was supported by Indonesian Endowment Fund for Education (LPDP Scholarship) which awarded to the writers in academic year 2017/2018. Additionally, this study was also recognized by School Research Ethic Committee of The School of Social Sciences, Education and Social Works of The Queen's University of Belfast, Northern Ireland, United Kingdom 2018.

\section{REFERENCES}

[1] N. Shaheen, International Students at UK Universities: Critical Thinking Related Challenges to Academic Writing, $\mathrm{PhD}$, thesis, University of Huddersfield, UK, 2012. Available at: http://eprints.hud.ac.uk/id/eprint/17499/

[2] J-C, G, Li, and JK, Yi, Asian international students' adjustment: Issues and program suggestions, College Student Journal, vol. 31, no. 4, 1997, pp. 473-479.

[3] Z. Zhang, and M. Brunton, Differences in living and learning: Chinese international students in New Zealand, Journal of Studies in International Education, vol. 11, no. 2, 2007, pp. 124-140.

[4] J. Campbell, and M. Li, Asian student's voices: An empirical study of Asian students' learning experiences in a New Zealand university, Journal of Studies in International Education, vol. 12, no. 4, 2008, pp. 375-396.

[5] R. B. Burns, Study and stress among first year overseas students in Australian university, Higher Education Research and Development, vol. 10, no. 1, 1991, pp. 61-78.

[6] G. Mullins, N. Quintrell, and L. Hancock, The experiences of international and local students: Three Australian universities, Higher Education Research and Development, vol. 14, no. 2, 1995, pp. 202-231.

[7] D. Pecorari, Academic Writing and Plagiarism: A Linguistic Analysis, London: Continuum, 2008.

[8] O, Majchrzak, Learner Identity and Leaner Beliefs in EFL Writing, Switzerland: Springer International Publisher, 2018.

[9] K. Hyland, Second Language Writing, Cambridge: Cambridge University Press, 2003.

[10] T. Silva, Toward an understanding of the distinct nature of L2 writing: The ESL research and its implications: The ESL research and its implications, TESOL Quarterly, vol. 27, 1993, pp. 665-677.
[11] E. Lavelle, and A. J. Guarino, A multidimensional approach to understanding college writing processes, Educational Psychology, vol. 23, 2003, pp. 295-305.

[12] E. Lavelle, and K. Bushrow, Writing approaches of graduate students, Educational Psychology, vol. 27, no. 6, 2007, pp. 807-822.

[13] R. Oxford, Teaching and Researching Language Learning Strategies, London: Routledge, 2011.

[14] M. Scardamalia, and C. Bereiter, Educational relevance of the study of expertise, Interchange, vol. 17 , no. 2 , 1986, pp. 10-24.

[15] Y. EngestrÖm, Expansive learning at work: Toward an activity of theoretical conceptualisation, Journal of Education and Work, vol. 14, no. 1, 2001, pp. 133-156.

[16] P. Prior, A Sociocultural theory of writing, in Handbook of Writing Research, C. A. McArthur, S. Graham, and J. Fitzgerald, Eds., New York: The Guilford Press, 2006, pp. 54-66.

[17] M. R. Lea and B. V. Street, Student writing in higher education: An academic writing approach, Studies in Higher Education, vol. 23, 1998, pp. 157-172.

[18] T. Lilis, M. Scott, Defining academic literacies research: Issues of epistemology, ideology and strategy, Journal of Applied Linguistic, vol. 4, no. 1, 2007, pp. 5-32.

[19] K. Kaufhold, Tracing interacting literacy practices in master's dissertation writing, London Review of Education, vol. 15, no. 1, 2017, pp. 73-84.

[20] C. Bazerman, Shaping Written Knowledge: The Genre and Activity of the Experimental Article in Science, Madison, WI: University of Wisconsin Press, 1988.

[21] C. Berkonkotter, and T. Huckin, Genre Knowledge in Disciplinary Communication, Hillsdale, New Jersey: Lawrence Erlbaum Associates, Inc, 1995.

[22] A. B. Marvasti, Qualitative Research in Sociology, London: Sage Publication, 2004.

[23] D. Ary, L. C. Jacobs, C. Sorensen, and A. Razavieh, Eds., Introduction to Research in Education, USA: Wadsworth Change Learning, 2010.

[24] J-H. Kim, Understanding Narrative Inquiry: The Craft and Analysis of Stories as Research, California: Thousand Oaks, 2016.

[25] M. B. Miles, and A. M. Huberman, Eds., An Expanded Book Qualitative Data Analysis, Thousand Oaks, California: Sage Publication. 
[26] R. G. Bogdan, and S. K. Eds., Qualitative Research for Education, Boston: MA: Allyn\& Bacon, 1992.

[27] L. Cohen, L. Manion, and K. Morison, Eds., Research Methods in Education, London: Routledge Falmer, 2000.

[28] M. Israel, and I. Hay, Research Ethics for Social Scientist: Between Ethical Conduct and Regulatory Compliance, Thousand Oaks, CA: Sage Publication.

[29] J. W. Creswell, Eds., Research Design Qualitative, Quantitative and Mixed Methods Approaches, London: Sage Publication, 2009.

[30] A. Wischgoll, Combined training of one cognitive and one metacognitive strategy improves academic writing skills, Frontiers in Psychology, vol. 7, no. 187, 2016, pp. 1-13.

[31] R. T. Kellogg, and A. P. Whiteford, Training advanced writing skills: The case for deliberate practice, Educational Psychology, vol. 44, 2009, pp. 250-266.

[32] C. Rinert, and H. Kobayashi, Situated writing practices in foreign language settings: The role of previous experience and instruction, in Writing in Foreign Language Contexts: Learning, Teaching and Researching, R. M. ManchÖn, Eds., UK, Bristol: Multilingual Matters, 2009, pp. 23-48.

[33] A. H. Fadda, Difficulties in academic writing: From perspective of King Saud University postgraduate students, English Language Teaching, vol. 5, no. 3, 2012, pp. 123-130.

[34] S. Adhikari, Beyond culture: Helping international students avoid plagiarism, Journal of International Students, vol. 8, no. 1, 2018, pp. 375-388.

[35] A. Imani, and H. Habil, NSS postgraduate students' academic writing: Problem-solving strategies and grammatical features, Procedia - Social and Behavioural Sciences, vol. 66, 2012, pp. 460-470. 